\title{
Homiletiese refleksie - 1 Korintiërs 15:1-20
}

\author{
Prof T F J Dreyer \\ Voorsitter: Kommissie van die Algemene Kerkvergadering van die \\ Nederduitsch Hervormde Kerk van Afrika \\ Hoof: Hervormde Teologiese Kollege, Fakulteit Teologie \\ Universiteit van Pretoria
}

\begin{abstract}
"En as Christus nie opgewek is nie, is ons prediking sonder inhoud en julle geloof ook sonder inhoud" (1 Kor 15:14).

Alle mense se lewensverhale eindig met 'n berig oor hulle dood. Die dood is die groot gelykmaker. Alle mense moet sterf: konings en knegte, ryk en arm.
\end{abstract}

Daar is antieke verhale bekend wat vertel van persone wat opgewek is en herleef het. In die Grieks-Romeinse wêreld is daar byvoorbeeld die verhaal van Herakles, die seun van Zeus. Op grond van sy leë graf en opstanding is hy as godeseun aangeneem. Ons beskou sulke verhale egter as mites omdat dit geen historiese werklikheidbegronding het nie. Dit is pogings om aan mense goddelike eienskappe toe te dig.

Vir ons as gelowiges en vir die kerk is daar ' $n$ ander lewensverhaal wat nie eindig met 'n slothoofstuk wat handel oor die persoon se dood nie, maar wat eindig met 'n berig oor sy opstanding en leë graf. - dit is die lewensverhaal van Jesus Christus! Jesus Christus is opgewek uit die dood! Hy leef! Hierdie verhaal het 'n werklikheidsaanspraak wat gegrond is in die vertellings oor sy leë graf en die berigte oor sy verskynings aan mense na sy opstanding. Die werklikheid dat Hy opgestaan het en lewe, gee sin en hoop aan ons lewe. Deur die krag van sy opstanding kan ons deur die geloof saam met Hom opstaan tot 'n nuwe lewe.

Dit is juis die betekenis van hierdie werklikheid wat Paulus in 1 Korintiërs 15 beredeneer. Hy grens hom hier veral af teen bepaalde gnostiese dwalings van sy tyd wat die opstandingsgeloof verwerp het. Die saak wat hy wil beredeneer, naamlik dat die opstanding van Jesus ' $n$ werklikheid is, is egter vir ons ook van lewensbelang. Paulus se 
keuse van woorde en styl beklemtoon die feit dat die opstanding van Jesus 'n werklikheid is waaraan ons nie moet twyfel nie. Hy roep 'n hele aantal mense as getuies wat sy uitsprake as die waarheid kan bevestig. Dit is almal mense aan wie Jesus na sy opstanding verskyn het: Petrus en die 12 dissipels; meer as 500 persone van die Pinkstergemeente; Jakobus en die ander apostels en laaste ook aan hom as Paulus. Sommige van die getuies het nog geleef. Dit is as 't ware asof Paulus sy lesers wil uitnooi: as julle daaraan twyfel, gaan vra hulle self. Hulle sal dit bevestig!

"As Christus nie opgewek is nie, is ons prediking sonder inhoud en julle geloof ook sonder inhoud". Hierdie boodskap van die opwekking van Jesus is die hart van die evangelie; dit is die fondament van die prediking; dit is die bron van ons geloof en hoop. As Christus nie opgewek is nie, is daar volgens die argumentering van Paulus, drie verreikende gevolge. Eerstens is ons dan nog almal vasgevang in ons sonde. Die dood en opstanding van Jesus Christus is volgens hom die bewys dat die sonde en die dood oorwin is. As Christus nie opgewek is nie, is ons nog steeds vasgevang in die sonde en die dood. Tweedens sal dit beteken dat almal wat in Christus gesterf het, verlore is. Dan het almal wat in hulle sterwensuur hulle hoop op Christus gevestig het, tevergeefs gehoop. Dit beteken dat die kerk deur die eeue heen miljoene gelowiges mislei het deur hulle te probeer vertroos met die boodskap van die opstanding van Christus! As Christus nie opgewek is nie, sal dit in die derde plek die konsekwensie inhou dat ons net vir hierdie lewe op Christus hoop. Dan is ons volgens Paulus die bejammerenswaardigste van alle mense!

Dit is juis hierdie hartaar van die kerklike verkondiging wat in die jongste tyd weer opnuut in die spervuur kom as gevolg van die resultate van die historiese Jesusnavorsing. Eintlik is hierdie navorsing oor die historiese Jesus al vir die afgelope 150 jaar aan die orde. Daar was verskillende fases in hierdie navorsing wat opgebloei en weer getaan het. Die jongste fase, die sogenaamde "renewed quest" is egter besig om met hulle resultate wêreldwyd opslae te maak. Volgens hierdie historiese navorsingsresultate word beweer dat daar geen historiese gronde bestaan vir die vertellings oor die leë graf en die opstanding nie. Jesus van Nasaret het volgens hulle 'n kruisdood gesterwe en is waarskynlik in 'n vlak graf daar naby begrawe, of sy liggaam het aan die kruis bly hang as prooi vir die aasdiere. Volgens hierdie navorsing het Jesus in die kerugma 
opgestaan. Dit beteken dat daar spoedig na Jesus se dood deur sy volgelinge daartoe oorgegaan is om Jesus te begin verkondig aan ander. Jesus die Verkondiger, het nou die Verkondigde geword. In hierdie verkondiging van die na-Pase Jesus is die latere vertellings oor die leë graf en sy verskynings na sy opstanding opgeneem. Hierdie kerugmatiese tradisielyn het veral neerslag gevind in die teologie van Paulus. Die berigte oor die verskyning van Jesus na sy opstanding wat ons in die evangelies aantref, is latere toevoegings gebaseer op besondere ervarings wat mense van Jesus gehad het, sogenaamde alter bewussynservarings.

Wat maak die kerk en ons as gelowiges met hierdie skokkende resultate? Is Jesus se opstanding dan inderdaad ook net 'n mite soos die van Herakles? Moet ons nou op historiese gronde net fokus op die historiese Jesus soos deur die resultate van die historiese ondersoek gerekonstrueer? Moet ons dan probeer terugkeer na sekere Jesus-groeperinge wat na Jesus se dood bestaan het. Daar was Jesus-volgelinge soos die Q-groep, die Tomas-groep, die Ebioniete en die Nasereners wat wel die leringe van Jesus nagevolg het, maar nie 'n verlossingsboodskap op sy opstanding gegrond het nie. Hierdie groeperinge het mettertyd doodgeloop, terwyl die Christene wat uit die kerugma van die opstanding geleef het, oor die hele wêreld versprei het, en tot vandag toe as kerk voortleef. As ons dan die resultate van die navorsing tot voorwaarde van ons geloof maak, impliseer dit inderdaad dat ons soos daardie vroegste Jesus-groeperinge maar blote navolgers word van 'n subversiewe wysheidsleraar, Jesus van Nasaret. Sy leerstellinge word dan die motto vir ons lewe!

Dan kan ons maar die kerkdeure toemaak! Wat maak ons dan anders as navolgers van groot geeste in die wêreldgeskiedenis? Dan kan mense maar self kies wie se leerstellings vir hulle die mees aanneemlikste is: dié van Marx, of Ghandi, of Jesus van Nasaret? Dan is ons inderdaad die bejammerenswaardigste van alle mense! Dan het die geloof ' $n$ ideologie geword! Dan is Paulus se woorde waar: "As Christus nie opgewek is nie, is ons prediking sonder inhoud en julle geloof ook sonder inhoud".

Daar is ' $n$ ander alternatief. Ons kan die wetenskaplike navorsingsresultate ignoreer. Ons kan terugval op proposisies waarin die waarheid vir tyd en ewigheid vasgevang is en deur geen nuwe vraagstelling geraak word nie. Dit is ook 'n doodloopstraat. Die mense van ons tyd sal steeds deur die media blootgestel word aan hierdie problematiek. 
Hierdie uitsprake en stellings wat as wetenskaplike feite aangebied word, skep by talle gelowiges verwarring en onsekerheid. As die opstanding van Jesus Christus geen werklikheidsbegronding het nie, raak die kerk en die geloof irrelevant.

Daar is nog 'n moontlikheid - 'n hermeneutiese moontlikheid! In die dialektiese spanning tussen geloof en geskiedenis, moet die kerk in die teologiebeoefening en deur die verkondiging die ruimtes oopbreek vir 'n groter werklikheid. Trouens, die postmoderne lewensklimaat en kenteorie skep juis die ruimte vir ' $n$ verbreding in die rasionaliteitsbegrip. Die werklikheid is groter as dit wat ons logies kan beredeneer of historieswetenskaplik kan bewys. Daar is 'n bowe-sintuiglike, bowe-empiriese werklikheid. Dit is 'n nie-bewysbare werklikheid - dit is God se werklikheid!

Miskien moet ons weer leer om eers onbevange te luister na dit wat die kerugma aan ons verkondig. Dit is interessant en van groot belang om daarop te let dat in die berigte in die evangelies oor die verskynings van Jesus na sy opstanding, asook die getuies wat Paulus hier noem, dit almal mense was wat getwyfel het en kleingelowig, of selfs ongelowig was. Dit lyk asof Jesus, as die opgestane Heer, spesiaal die moeite doen om juis die twyfelaars en die kleingelowiges op te soek en met hulle in ontmoeting te tree. Tomas het gesê hy sal nooit glo as hy nie sintuiglik oortuig kan word dat Jesus werklik opgestaan het nie. Sien is glo - dit moet eers sintuiglik, wetenskaplik bewysbaar wees. Petrus het in die krisisoomblik toe Jeus gevange geneem is, begin twyfel. Dit was vir hom duidelik dat die Jesus-saak misluk het. Dit was nie die moeite werd om jou lewe daarvoor te waag nie - daarom het hy Jesus verloën! Jakobus, Jesus se broer, het op 'n stadium gesê Jesus is kranksinnig. Dit wat Hy leer sal niemand met 'n gesonde logika aanvaar nie. Hy moet maar gerus gaan probeer om dit in Jerusalem kwyt te raak, daar sal die skrifgeleerdes Hom gou op sy dwaasheid wys. Paulus kon met sy teologiese skoling tot geen ander gevolgtrekking kom as dat Jesus 'n dwaalleraar was wat 'n valse leer verkondig het nie. Hy het daarom geen ander keuse gehad as om die Christene te vervolg nie.

Dan gebeur dit dat Jesus na sy opstanding aan hulle verskyn. In hulle ontmoeting met die opgestane Heer word hulle bewus van 'n groter werklikheid. Dit is 'n werklikheid wat hulle nie logies kan uitredeneer, of sintuiglik-wetenskaplik kan bewys nie, maar die oomblik toe hulle in die geloof bewus geword het van hierdie werklikheid, het 
dit in hulle lewens 'n radikale verandering veroorsaak. Tomas het bely: "My Here en my God". Petrus het gesê: "Here, U weet alles, U weet dat ek U liefhet". Hy het die opdrag ontvang om die kudde op te pas. Jakobus het, nadat Jesus aan hom verskyn het, hom vir die voortgang van die kerk beywer en die groot kerkleier in Jerusalem geword. Paulus het, nadat Jesus aan hom verskyn het op die pad na Damaskus, van 'n vervolger tot die groot verkondiger van Jesus Christus geword.

Die oplossing lê daarin dat die kerk, deur sy teologie en verkondiging, weer die waagmoed van die geloof sal openbaar om die ruimte te skep dat mense in verwondering kan ontdek dat daar 'n groter werklikheid is as die werklikheid wat ons wetenskaplikhistories kan bewys! God is groter as ons wetenskap en denke! Ons moet in geloofsoortuiging verkondig dat Jesus opgestaan het en leef! Thomas, jy wat alles wetenskaplik wil bewys en twyfel - in die ontmoeting met Jesus sal jou twyfel verdwyn. Petrus, jy wat moedeloos word en dink nou is die saak van die kerk 'n verlore saak - die opgestane Heer wil jou ontmoet en nieteenstaande jou verloëning jou weer in sy diens gebruik. Jakobus, dit wat jy met jou gesonde verstand as kranksinnig afmaak, word in die teenwoordigheid van die lewende Heer juis dit wat aan jou lewe sin gee. Paulus, jy wat op grond van die insigte van jou teologiese kennis die kerk vervolg het - deur 'n Damaskus-ervaring sal jy die groot teoloog van ons tyd word!

Deur die verkondiging van die Woord en deur die kragtige werking van sy Gees wil Jesus Christus met mense van ons tyd in ontmoeting tree. As ons dit met geloofsoortuiging verkondig, gebeur die wonder dat mense deur die geloof saam met Hom opstaan tot 'n nuwe lewe. Waar dit gebeur ervaar die wêreld iets van die trilling van 'n aardbewing, omdat die ewigheid in die tyd deurgebreek het! 